\title{
The human right to a satisfactory environment and the role of the African Court on Human and Peoples' Rights
}

\author{
By Sunday Bontur Lugard*
}

\begin{abstract}
Every legally recognized right requires a system for its realization or enforcement. This raises the need for institutions that help in their implementation. The African Court exists as a link between the objectives of the African Charter on Human and Peoples' Rights and their realization. In the context of environmental right to a satisfactory environment, the Court alongside its subregional courts, have fared commendably well in their purposive interpretation of the right, though there are still unanswered question regarding the contours of the right. Even though not too many cases have come up for determination based on the article 24 claims, the few reviewed here give credence to the pursuit of the goal of achieving a sustainably clean environment on the continent.
\end{abstract}

\section{Introduction}

The African Charter on Human and Peoples' Rights (the African Charter) was drafted on a premise that reflects the tripod of the generations of human rights. Unlike other regional charters, it mainstreams the provision and the realization of civil and political, socio-economic and cultural rights, as well as solidarity rights - this is consistent with African value system and historical foundation of ubuntu. ${ }^{1}$ It is reputed to be the first and only binding international instrument to recognize third generation or solidarity rights of peoples - rights relating to existence, equality, self-determination, sovereignty over natural resources, peace, development, and especially the environment. ${ }^{2}$

* Sunday Bontur Lugard, Jus Associates and University of Jos, Nigeria; lugards@unijos.edu.ng.

1 Ubuntu (fully expressed as umuntu ngumuntu ngabantu) is a South African proverb that has gained notoriety on the continent because of its embodiment of African solidarity. It literally means "a person is a person through people." See Furthermore, Justice Langa discussed ubuntu as an African social theory thus: "we are not islands unto ourselves' [but are a] communality and the inter-dependence of the members of a community [entails] that every individual is an extension of others." See BE Winks, "A Covenant of Compassion:

African Humanism and the Rights of Solidarity in the African Charter on Human and Peoples' Rights" (2011) 11 African Human Rights Law Journal 456.

2 B. E Winks, "A Covenant Of Compassion: African Humanism And The Rights Of Solidarity In The African Charter On Human And Peoples' Rights," (2011) 11 African Human Rights Law Journal $453<$ Http://Www.Lawjournals.Org/Download/523/5-4-62-507.Pdf $>$ Accessed 30 September 2021. 
What does the right to a "satisfactory environment" entail in the context of the African Charter?

Article 24 of the African Charter provides that "All peoples shall have the right to a general satisfactory environment favourable to their development." The Charter does not define what "the right to a general satisfactory environment" entails and this has given room to a barrage of individual interpretations. ${ }^{3}$ It has however been considered to reflect several ramifications, including the "right to a satisfactory environment", the "right of the environment" and environmental rights.

a. The "right to a satisfactory environment" as a substantive right may be considered as "the right to conserve, protect and improve the current environment" for the benefit of man. Essentially, this is substantive in character and anthropocentric in perspective. This does not place any intrinsic value on nature but on it as valuable for the sustenance of human life.

b. On the other hand, "the right of the environment" is founded upon the notion that the environment possesses rights derived from its own intrinsic value, separate and distinct from human use of the environment". ${ }^{4}$ This right of the environment or nature has gained notoriety and some scholarly discourse ${ }^{5}$ and even recognized in some African jurisdictions like Kenya. ${ }^{6}$ It raises posers like; does the environment as a distinct element have right worthy of human protection, or environmental rights are all about protecting the right of man to use the environment without regards to any eco-centric consideration? Christopher Stone ${ }^{7}$ contends that the demand for the right of natural non-animate objects does not entail, for instance, a bar on the cutting down of trees nor is it the case that they are expected to have the same rights as human beings. ${ }^{8} \mathrm{He}$ believes that at common law, natural objects are not holders of rights, and courts have

3 Emeka Polycarp Amechi, "Enhancing Environmental Protection And Socio-Economic Development In Africa: A Fresh Look At The Right To A General Satisfactory Environment Under The African Charter On Human And Peoples' Rights" (2009) 5(1) Law, Environment and Development Journal $64<\mathrm{http}$ ://www.lead-journal.org/content/09058.pdf > accessed 1 October 2021.

4 See Le Rodriguez-Rivera "Is The Human Right To Environment Recognised Under International Law? It Depends On The Source" (2001)12 Colorado International Environmental Law and Policy 1.

5 See David R. Boyd, The Right of Nature: A Legal Revolution That Could Save the World (ECW Press, 2017); Stone C, Should Trees Have Standing? And Other Essays on Law, Morals and the Environment (New York, Oceana Publishing, 1972); Erin O'Donnell and Julia Talbot-Jones, "Creating legal rights for rivers: lessons from Australia, New Zealand, and India" (2018) 23(1) Ecology and Society <https://willamette.edu/law/resources/journals/welj/pdf/2016/2016-f-welj-pieta ri.pdf $>$ accessed 7 June 2020.

6 Article 42 of the Constitution of Kenya 2010 - see the judicial interpretation concerning the right of nature in Joseph Leboo \& 2 others v Director Kenya Forest Services \& another 2013 eKLR <http:// kenyalaw.org/caselaw/cases/view/92434/>, accessed 19 April 2018.

7 Stone C, Should Trees Have Standing? And Other Essays on Law, Morals and the Environment (New York: Oceana Publishing, 1972).

8 Ibit at 10. 
in certain situations issued injunctions against pollution of stream, but the streams in themselves are "fundamentally rightless." For the pollution of the stream to be stopped at common law, someone (another human being - a riparian) must show the invasion of his right by the polluter, the stream not being a right-holder, hence lacking standing to sue for itself. ${ }^{9}$

In addition, he argues that common law deprives natural objects "rights" by focusing on protecting the right of property owning human being "with minimal weighing of any values." 10 He makes an intriguing argument by further fortifying his philosophy with the below example. In a case of pollution by an upper riparian (upstream user), the court tries to balance the economic interest of the upstream, as well as downstream user; but "What does not weigh in the balance is the damage to the stream, its fish and turtles and 'lower life'. So long as the natural environment itself is rightless, these are not matters for judicial cognizance. ${ }^{11}$ Asides standing, he states that the common law makes natural objects "rightless" in the area of the benefit of a favourable judicial outcome as no money goes to stream to repair it as natural objects at common law and even some statutory law are mere objects for man to conquer and master and use. ${ }^{12}$

In buttressing the need for the right of the environment in itself, he argues that there has been no major call for the recognition of a new right that was not greeted by resistance from the recognized rights holders of the time, hence that should not form an excuse for the jettisoning the recognition of the right of the environment as a distinct legal right.

c. On its part, "environmental rights" "encapsulate the procedural human rights necessary for the implementation of the substantive rights that are part and parcel of the expansive right to a satisfactory environment. ${ }^{13}$ The procedural content of the right to a satisfactory environment under the African Charter invariably implicates procedural rights such as the right to have access to information affecting one's environment, the right to participate in decisions affecting the environment including prior environmental impact assessment, and right to seek redress in the event of environmental degradation. ${ }^{14}$

These arguments on the appropriate contours of environmental rights, and particularly the right to a satisfactory environment as envisaged under the African Charter can best be appreciated in the context of the enforcement of this right by the African Court or interrelated international courts.

9 Ibid at 12 .

10 Ibid at 13 .

11 Ibid at 14.

12 Ibid.

13 Ibid at 15.

14 Emeka Polycarp Amechi, "Enhancing Environmental Protection And Socio-Economic Development In Africa: A Fresh Look At The Right To A General Satisfactory Environment Under The African Charter On Human And Peoples' Rights" (2009) 5(1) Law, Environment and Development Journal $63<$ http://www.lead-journal.org/content/09058.pdf> accessed 1 October 2021. 


\section{The African Court on Human Rights and the huge burden of Realizing the "right to a satisfactory environment."}

The African Court on Human and Peoples' Rights is the judicial arm of the African Union and one of the three regional human rights courts together with the European Court of Human Rights and the Inter-American Court of Human rights. It was established to protect the human and peoples' rights in Africa principally through delivery of judgments. The Court has its permanent seat in Arusha, the United Republic of Tanzania. ${ }^{15}$ The Court was established by article 1 of the Protocol to the African Charter on Human and Peoples' Rights on the Establishment of an African Court on Human and Peoples' Rights (the Protocol). The Protocol establishing the Court was adopted on 9 June 1998 in Burkina Faso and came into force on 25 January 2004 after it was ratified by more than 15 countries. ${ }^{16}$ The mandate of the Court is to complement and reinforce the functions of the African Commission on Human and Peoples' Rights (the African Commission - often referred to as the Banjul Commission), which is a quasi-judicial body charged with monitoring the implementation of the Charter. ${ }^{17}$

The jurisdiction of the Court has not been activated concerning a substantially environmental rights issue, but on interconnected and other issues that have implications for the state of the environment or border on the realization of the goal of achieving a "a satisfactory environment".

In African Commission on Human and Peoples' Rights $v$ Kenya, ${ }^{18}$ the Court was confronted with the case dealing with the eviction of an indigenous population, the Ogiek people, from the Mau Forest in Kenya. They were issued a 30-day notice to vacate the forest in 2009. Considering the implications of the enforcement of the notice against the victims, the Court issued an Order of Provisional Measure suspending the execution of the eviction notice by the Kenya Forestry Service. Among other claims, the Ogiek people contended that the eviction notice violated article 21 of the African Charter. It was their claim that the respondent violated the rights of the Ogieks to freely dispose of their wealth and natural resources in two ways. Firstly, by evicting them from the Mau Forest and denying them access to the vital resources therein, and secondly, by granting logging concessions on Ogiek ancestral land without their prior consent and without giving them a share of the benefits in those resources. The Court found for the Applicants by holding that their rights to freely dispose of their wealth and natural resources under article 21 (the right to free disposal of wealth and natural resources) has been violated by the Kenyan government. Though the issue of the environment was not chiefly in issue, the Court held that "nothing prevents other peoples' rights, such as the right to development (Article 22),... or the right

15 The African Court on Human and Peoples' Rights <https://www.african-court.org/wpafc/basic-inf ormation/\#establishment> accessed 1 October 2021.

16 Ibid.

17 Ibid.

18 (merits) (2017) 2 AfCLR 9. 
to a healthy environment (Article 24) from being recognised, where necessary, specifically for the ethnic groups and communities that constitute the population of a State." 19 This obiter dictum sets the stage for victims of environmental rights violation on the continent to seek redress from the court after meeting all preconditions for the determination of such right.

This position had been earlier accentuated in Social and Economic Rights Action Center (SERAC) and another v. Federal Republic of Nigeria ${ }^{20}$ (SERAP v. Nigeria) determined by the African Commission, the substantive issue of the realization of the right to satisfactory environment by the Ogoni people of the Niger Delta region in Nigeria was considered and determined in favour of the community which was a victim of oil pollution. the African Commission assumed jurisdiction, citing its earlier decisions, ${ }^{21}$ in this matter despite the complainants' inability to exhaust local remedies requirement which is intended to give the domestic courts an opportunity to decide upon cases before they are brought to an international forum. ${ }^{22}$

In the African Commission declared that Nigeria had breached its obligations to respect, protect, promote, and fulfill rights guaranteed by the African Charter. Among other violations, Nigeria was found liable for violating rights guaranteed under articles 22 (right of the people to freely dispose of their wealth and natural resources) and article 24 (the right of peoples to a "general satisfactory environment favourable to their development"). The Commission declared further that the right to a general satisfactory environment, as guaranteed under Article 24 of the African Charter or the right to a healthy environment, as it is widely known, therefore imposes clear obligations upon government. It requires the State to take reasonable and other measures to prevent pollution and ecological degradation, to promote conservation, and to secure an ecologically sustainable development and use of natural resources. The Commission found the Federal Republic of Nigeria to be in violation of Articles 2, 4, 14, 16, 18(1), 21 and 24 of the African Charter, and appealed to it to ensure the protection of the environment, health and livelihood of the people of Ogoniland by investigating and prosecuting government officials and the state owned Nigerian National Petroleum Corporation (NNPC) for any form of violation of human rights. ${ }^{23}$ The Nigerian state has not taken any action since the decision was made over a decade ago, and no sanction of whatever nature has been meted on it till date.

Asides the African Court's determination of environmental rights issue, the sub-regional courts, particularly the ECOWAS Community Court has had event to interpret article 24 of the African Charter.

19 Ibid.

20 Communication 155/96.

21 Communications 25/89, 47/9 0, 56/9 1, 100/9 3, World Organization Against Torture et al. /Zaire, Communication 60/9 1Constitutional Right Project/Nigeria and Communication 101/9 3 Civil Liberties Organisation/Nigeria.

22 Ibid., paragraph 38.

23 SERAC v. Nigeria (supra). 


\section{Sub-regional courts: ECOWAS, East and Southern Africa Court}

In the same vein, the Economic Community of West African States (ECOWAS) Community Court in SERAP v. Federal Republic of Nigeria, ${ }^{24}$ found the Nigerian government responsible for abuses by oil companies operating within its territory, in violation of, among other things, Article 24 of the African Charter of Human and Peoples' Rights. The Court held, among others that:

1. the "environment is essential to every human being," and that "[t]he quality of human life depends on the quality of the environment."

2. the responsibility of Nigeria is to hold accountable actors that cause environmental harm through oil pollution, and to ensure adequate reparation is provided for the victims.

3. Nigeria is under an obligation to take "additional and concrete measures aimed at preventing the occurrence of damage or ensuring accountability, with the effective reparation of the environmental damage suffered."

4. Nigeria had not seriously and diligently held accountable any of the perpetrators of the many acts of environmental degradation which occurred in the Niger Delta Region.

5. the duty assigned by Article 24 is "both an obligation of attitude and an obligation of result," and that Article 24 requires the State to adopt legislative or other measures to give effect to the right, and that such measures must be implemented to promote accountability and to ensure adequate reparation for environmental damage.

This decision underscores the long-held view that the Nigerian government either shields the oil companies from environmental liability because of the economic benefits of their operations, or the regulatory agencies are incapable of summoning effective institutional response necessary to set the pace for sustainable petroleum operations in the Niger Delta area.

Apart from the ECOWAS Court, the East African Court of Justice considered a similar situation in the case of African Network for Animal Welfare (ANAW) v. The Attorney General of the United Republic of Tanzania. ${ }^{25}$ This matter borders on the protection of the Serengeti ecosystem for the sake of future generations and whether the road project being initiated has potential for inflicting irreparable damage to the environment. The EACJ in its first instance judgement held that:

A declaration is hereby issued that the initial proposal or the proposed action by the Respondent to construct a road of bitumen standard across the Serengeti National Park is unlawful and infringes Articles 5(3)(c),8(1)(c),111(2) and 114(1) of the Treaty. ii) A permanent injunction is hereby issued restraining the Respondent from

24 Socio-Economic Rights and Accountability Project (SERAP) v. Federal Republic of Nigeria No. $\mathrm{ECW} / \mathrm{CCJ} / \mathrm{JUD} / 18 / 12$ (2012).

25 Reference No. 9 Of $2010<$ https://www.eacj.org/?cases=african-network-animal-welfare-anaw-vs -attorney-general-united-republic-tanzania > accessed 1 October 2021. 
operationalising its initial proposal or proposed action of constructing or maintaining a road of bitumen standard across the Serengeti National Park subject to its right to undertake such other programmes or initiate policies in the future which would not have a negative impact on the environment and ecosystem in the Serengeti National Park."

The appellate division of the Court held that articles 111-114 of EAC Establishment Treaty relating to environmental standard and obligations of the member states was self-executing and do not require protocol to give vent to its provisions. It further reiterated the right of citizens to institute this sort of claim against the state without the need to establish personal injury. Though this was not a matter that was determined based on article 24 of the African Charter, upholding the right of the people Serengeti people to a satisfactory environment under the sub-regional instrument has the same effect of enhancing the realization environmental rights of the people.

This further demonstrates the viability of the African Court or its sister institutions as effective tools for the pursuit of, and realization of the right to a satisfactory environment provided for in article 24 of the African Charter. The solidary flavour in the right-based approach to the protection and fulfilment of this right among the African people holds the key to enthroning environmental accountability and governments' responsibility for the fulfilment of a satisfactory environment necessary for development on the continent.

\section{Domestic realization}

In pursuit of State parties' responsibility under the African Charter, many of them have made constitutional provisions supporting the realization of the goal of a generally satisfactory environment favourable to their people's development. For instance, the constitutions of some of these countries use the below expressions:

South Africa: "Everyone has the right-

(a) to an environment that is not harmful to their health or well-being...."26. In the celebrated case of Director: Mineral Development, Gauteng Area and Sasol Mining (Pty) Ltd $v$ Save the Vaal Environment and Others ${ }^{27}$, the court held that "Our Constitution, by including environmental rights as fundamental justiciable human rights, by necessary implication requires that environmental considerations be accorded appropriate recognition and respect in the administrative process in our country." 28 The position in South Africa as shown in the above case is the direct interpretation of a substantive environmental right guaranteed by the constitution and not the expansive

26 Section 24, Constriction of the Republic of South Africa No. 108 of 1996.

27 (1999) 2 SA 709 (SCA) at 719 quoted in Glazewski, J, Environmental Law in South Africa (Durban: Lexis Nexis, 2004) 67.

28 Ibid. 
interpretation of Fundamental Objective and Directive Principle of State Policy - an option adopted in Nigeria and Ghana, among others.

Furthermore, the Kenyan constitution provides that "Every person has the right to a clean and healthy environment, which includes the right -

(a) to have the environment protected for the benefit of present and future generations through legislative and other measures, particularly those contemplated in Article 69; and

(b) to have obligations relating to the environment fulfilled under Article 70." 29

In Joseph Leboo \& 2 others $v$ Director Kenya Forest Services \& another ${ }^{30}$ the Judge observed concerning representative action aimed at the realization of the right to a clean and healthy environment thus:

...in my view, any person is free to raise an issue that touches on the conservation and management of the environment, and it is not necessary for such person to demonstrate, that the issues being raised, concern him personally, or indeed, demonstrate that he stands to suffer individually. Any interference with the environment affects every person in his individual capacity, but even if there cannot be demonstration of personal injury, such person is not precluded from raising a matter touching on the management and conservation of the environment....Any person, without the need of demonstrating personal injury, has the freedom and capacity to institute an action aimed at protecting the environment. The plaintiffs have filed this suit as representatives of the local community and also in their own capacity. The community, of course, has an interest in the preservation and sustainable use of forests. Their very livelihoods depend on the proper management of the forests. Even if they had not demonstrated such interest that would not have been important, as any person who alleges a violation of any law touching on the environment is free to commence litigation to ensure the protection of such environment.... ${ }^{31}$

In the case of Ghana, section 36(9) of its 1996 Constitution and Nigeria's section 20 have similar implications - they are generally non-justiciable. In Nigeria, for instance, section 20 of the Constitution of the Federal Republic of Nigeria 1999 (as amended) provides that "[t]he State shall protect and improve the environment and safeguard the water, air and land, forest and wildlife of Nigeria." 32 However, section 6(6)(c) of the same constitution makes the provisions of chapter 4 , being matters under the fundamental objectives and

29 Section 42, the Constitution of Kenya, 2010.

$302013 \mathrm{eKLR}<\mathrm{http} / / /$ kenyalaw.org/caselaw/cases/view/92434/>, accessed 19 April 2018.

312013 eKLR, Environment and Land No. 273 of 2013, quoted in Muigua, K, "Reconceptualising the Right to Clean and Healthy Environment in Kenya" $(2015)<\mathrm{http}: / /$ www.kmco.co.ke/at tachments/article/161/RIGHT\%20TO\%20CLEAN\%20AND\%20HEALTHY\%20EN VIRONMENT\%20IN\%20KENYA.docx\%207th\%20september\%202015.pdf > accessed 27 March 2017.

32 Constitution of the Federal Republic of Nigeria (as Amended), section 20 thereof. 
directive principles of state policy non-justiciable. The implication is that this is merely a "policy directive" and cannot be subject of litigation, as far as the right claim/flavour is concerned.

This is not conclusive though, as the derivative interpretation approach to the interpretation of constitution mainly adopted by Indian courts as shown in NG Thirumulpad $v$. Union of India \& $\mathrm{Ors}^{33}$ has found its way into the Nigerian judicial system. In Jonah Gbemre v. Shell \& $\mathrm{Ors}^{34}$ the Judge of the Federal High Court held that the right to life and dignity of human person guaranteed under sections 33 and 34 respectively of the 1999 Constitution of the Federal Republic of Nigeria (as Amended) inevitably include the right to clean, poison-free, pollution-free healthy environment. He further stated that the continuing flaring of gas by Shell during their oil operations and production in the applicant's community was a "gross violation of their fundamental right to life (including healthy environment)."

This position in Nigeria has further been strengthened by the Supreme Court's recognition of public interest litigation in environmental matters as an approach that is lawfully recognized by the extant legal system. See the recent case of Centre for Oil Pollution Watch v. NNPC. ${ }^{35}$ Challenges and the way forward

From the cases or communications determined by the African Court or its interconnected courts, only one of the three dimensions of environmental right has so far been tested by it: the substantive anthropocentric right to a clean environment - as shown in African Commission on Human and Peoples' Rights $v$ Keny $a^{36}$ and SERAC v. Nigeria. ${ }^{37}$ The other two dimensions (the right of the environment or nature and the procedural right - right to access information on environmental matters and to participate in decision making on same) have not yet been subject to the determinative or interpretative jurisdiction of the African Court.

To complete the circle of the protection of the environment, there is need to incorporate these two elements into the province of the right to a clean environment recognized by the African Charter. This can take the form of the intervention by way of extensive interpretative jurisdiction of the court or through a protocol. At national levels (globally), several national constitutions, including those of Ecuador, Kenya, Bolivia, among others, have held that interested parties have been held to have the standing, as trustees of nature, to institute legal proceedings on behalf of it with the aim of protecting it from anthropogenic environmental harm. ${ }^{38}$ This claim however is an evolving addition to the human rights philosophy

34 Suit No.: FHC/B/CS/53/05 delivered on the $14^{\text {th }}$ November 2005.

35 (2019) 5 NWLR (Pt. 1666) 518.

36 Supra.

37 Supra.

38 Section 71 of the Ecuadorian Constitution, 2008; Article 42 of the Constitution of Kenya 2010 see the judicial interpretation concerning the right of nature in Joseph Leboo \& 2 others v Director 
that is yet to crystallize but has gained currency as an emerging environmental rights protection platform in some jurisdictions in Africa, Australia and South America. ${ }^{39}$ The key reason for some scholars' rejection of the concept is in its inability to clearly delineate the province of "right-holders" and "burden-bearers" that is an inescapable precondition for the recognition of a new right under the traditional human rights philosophy. However, this would appear to be an exception to the general requirement for the emergence of a new right. In terms of enforceability, Kenya has blazed the trail in Africa and has proved its effectiveness as a reliable tool for environmental protection. ${ }^{40}$

On the issue of procedural right, this right does not accord any substantive benefit to the beneficiary, but imposes responsibility on the burden-bearer to take certain steps, for example, consult with the right-bearers before taking certain decisions as affecting the environment. These rights may include imposing on governments the duty to consult with communities before taking actions that have the potentials to negatively impact their environment, or giving individuals the right to participate in governmental processes that will affect their environment. ${ }^{41}$ Procedural rights do not guarantee a particular outcome; however, they may be more useful in preventing environmental degradation. ${ }^{42}$ A typical example of this sort of right is enshrined in the UN Economic Commission for Europe (UNECE) Convention on Access to Information, Public Participation in Decision-Making, and Access to Justice in Environmental Matters (Aarhus Convention). ${ }^{43}$ Another example

Kenya Forest Services \& another 2013 eKLR <http://kenyalaw.org/caselaw/cases/view/92434/>, accessed 19 April 2018.

39 See articles 71-74 of the Constitution of the Republic of Ecuador 2008. The Bolivian Law of the Rights of Mother Earth 2010 are two key examples. Legislation in New Zealand has expressly recognized certain rivers, including the Whanganui River, as legal entities under the law. See Preston, B.J, "The challenges of approaching judging from an Earth-centred perspective" (2007) address at the launch of the book by Rogers, N and Maloney, M (eds), Law as if Earth Really Mattered: The Wild Law Judgment Project (Routledge, 2017) <http://www.lec.justice.nsw.gov.au/Documents/ Speeches\%20and\%20Papers/PrestonCJ/PrestonCJThe $\% 20$ chall enges $\% 20$ of $\% 20$ approaching $\% 20$ judging $\% 20$ from $\% 20$ an $\% 20$ earth\%20centred\%20perspective.pdf $>$ accessed on 4 November 2018. In Kenya, the court has ingeniously permitted the use of the public interest litigation of environmental rights issues to empower concerned persons to institute legal proceedings on behalf of the environment - see Joseph Leboo \& 2 Others v Director Kenya Forest Services \& Another (supra).

40 Kenya does not directly recognize a stand-alone right of the environment, but it permits public interest litigation undertaken by members of the public with a view to protecting the environment as a distant good under threat of harm - see the judgement of the High Court of Kenya in Joseph Leboo \& 2 Others v Director Kenya Forest Services \& Another (supra).

41 Daly, E, "Constitutional Protection for Environmental Rights: The Benefits of Environmental Process" (2012) 17(2) International Journal of Peace Studies $71<\mathrm{https}: / /$ www.gmu.edu/programs/i car/ijps/Vol17_2/Daly\%20Constitutional\%20Protection.pdf> accessed 7 October 2016.

42 Ibid.

43 Aarhus (Denmark), 25 June 1998, in force 30 Oct. 2001, <http://www.unece.org/env/pp/welcome. html $>$. 
can be found in the Environmental Impact Assessment Act ${ }^{44}$ which mandates NESREA to present information on a proposed project for public comments before taking a decision on whether to grant its permission or not.

The key impediments to the realization of the human right to a generally satisfactory environment include the following:

a. The problem of interpretation of the import and the contours of the right to a satisfactory environment.

b. Low level of public interest litigation on the continent.

c. The cost of approaching the court in Arusha, Tanzania and engaging legal representatives is certainly out of the reach of the ordinary African.

d. The requirement of exhausting domestic legal remedies as a precursor to igniting the jurisdiction of the court is also a clog to realizing this right in some countries as the entire process is time consuming.

In search for the way forward, there is the need to consider some improvements on the legal and institutional frameworks targeted at smoothening the path to easily enforceable justice for communities that become victims of such solidary right violation in the context of the African Court. The African Court should in subsequent cases define the extent of the "general satisfactory environment favorable to their development" envisaged by the Charter so as to guide litigants and enhance legal scholarship. This would guide member states in couching municipal legislations and policies aimed at realizing the goals of the Charter. Secondly, the Africa Union should set up a human rights fund wherefrom indigent communities can access financial support to prosecute claims of violations of right to a satisfactory environment. Contributions into the fund can be sought from international ENGOs, international institutions with human rights mandate, private persons, among others.

On the requirement of exhausting internal legal remedies as a precondition for igniting the jurisdiction concerning a violation claim, it has the potency of frustrating parties as the local process may be wearisome and time consuming. The ECOWAS Community Court has set a good example by allowing victims of such rights violations to approach it, even as a court of first instance, hence giving parties the opportunity to choose whether to approach it or municipal courts. This way, time and other resources can be saved.

\section{Conclusion}

The African Charter is the only international instrument that mainstreams the realization of the right to a "satisfactory environment" as an entitlement of the "peoples" as demonstrated in SERAC v. Nigeria ${ }^{45}$ and African Commission on Human and Peoples' Rights

44 Section 7, Environmental Impact Assessment Act, Cap. E12, Laws of the Federation of Nigeria, 2004.

45 Supra. 
$v$ Kenya $^{46}$. Though not too many cases have come before the African Court on issues directly bordering on the right of the people to a satisfactory environment, required for a satisfactory economic, social and other activities, it still holds the potential to addressing the environmental rights violations on the continent that affect communities like the Niger Delta (in Nigeria) and Ogiek people (in Kenya) as examples for other communities that are or have or are likely to be negatively affected by natural resources-based corporations and government developmental initiatives that have the potential to adversely impact on the environment on a largescale. The African Court may not have defined clearly what the right to a "satisfactory environment" entails, but the above judgements do not leave us in doubt about the capacity of the legal framework (article 24 of the African Charter) and institutional framework (the African Court) to inspire the protection, respect for and the fulfilment of the several dimensions to the right to a clean and healthy environment as a solidary right on the continent. 